\title{
LANGKAH-LANGKAH PENGEMBANGAN MEDIA PEMBELAJARAN MENUJU PENINGKATAN KUALITAS PEMBELAJARAN
}

\author{
Oleh: \\ Tatta Herawati Daulae ${ }^{1}$
}

\begin{abstract}
Abstract

This paper explained about the media development toward the improvement of learning quality. This is also contains conceptual information traced through books that are relevant to the literature study approach. The finding of this paper is there were a connection between learning media development to learning quality improvement. This paper is only traced the concept that can achieve the learning quality improvement. Based on that reason, this paper can still be continued by other researcher deeply in practical term.
\end{abstract}

Keyword: Media, learning, learning quality

\section{PENDAHULUAN}

Peningkatan kualitas pembelajaran adalah suatu kemutlakan yang merupakan pusat perhatian dan peningkatan kualitas menjadi tujuan semua tingkatan pendidikan, dengan tercapainya kualitas pembelajaran, maka akan meningkatkan mutu pembelajaran. Salah satu dari komponen-komponen belajar tersebut adalah media pembelajaran. Media pembelajaran ini merupakan benda dan alat bantu yang digunakan dalam pembelajaran, untuk merangsang pikiran untuk memahami pelajaran, sekaligus membekali kompetensi siswa. Media sebagai alat bantu dapat juga berfungsi untuk memperlancar proses belajar mengajar, sekaligus untuk memudahkan pencapaian tujuan pembelajaran.

Sehubungan dengan perkembangan pengetahuan dan teknologi, khususnya dalam bidang pendidikan, maka semakin mengupayakan keberadaan berbagai macam media pembelajaran mulai dari tingkat pendidikan yang rendah dan sampai pada tingkat yang tinggi. Dengan tujuan untuk meningkatkan kualitas belajar karena dengan meningkatkan kualitas, akan memudahkan tercapainya tujuan. Maka salah satu peningkatan kualitas pembelajaran adalah dengan menggunakan media dalam pembelajaran, maka dalam penggunaan media ini ada langkah-langkah pengembangannya yang harus diperhatikan oleh guru.

${ }^{1}$ Penulis Adalah Dosen FTIK IAIN Padangsidimpuan. 


\section{PEMBAHASAN DAN ANALISIS KONSEP}

\section{A. Pengertian Media Pembelajaran}

Kata media berasal dari bahasa Latin dan merupakan bentuk jamak dari kata medium yang secara harfiah berarti perantara atau pengantar. Media adalah perantara atau pengantar pesan dari pengirim kepenerima pesan. ${ }^{2}$

Banyak batasan tentang media, asosiasi Teknologi dan komunikasi Pendidikan Associtation Of Educatin and Communikation Teknologi/AECT di Amerika, Mendefenisikan media sebagai segala bentuk dan saluran yang digunakan orang untuk menyalurkan pesan/informasi. ${ }^{3}$ Gagne menyatakan bahwa media adalah berbagai jenis komponen dalam lingkungan siswa yang dapat merangsangnya untuk belajar.

Asosiasi Pendidikan Nasional National Education Association/NEA memiliki pengertian yang berbeda. Media adalah bentuk-bentuk komunikasi baik tercetak maupun audiovisual serta peralatannya. Media hendaknya bisa di manipulasi, dapat dilihat, didengar dan dibaca/dibicarakan beserta instrument yang dipergunakan dengan baik dalam kegiatan belajar mengajar, dapat mempengaruhi efektifitas program instruksional. ${ }^{4}$ Basyiruddin mengatakan bahwa media adalah "Manusia" benda atau peristiwa yang membuat kondisi siswa memungkinkan memperoleh pengetahuan, keterampilan atau sikap. ${ }^{5}$

Pengertian lain Bevec, 1997, media adalah sebuah alat yang mempunyai fungsi menyampaikan pesan. Yunus Namsa mengatakan, media adalah alat sarana komunikasi yang dapat dipakai sebagai penghubung, perantara dalam pendidikan.

Menurut Purnamawati dan Eldarni, media merupakan segala sesuatu yang dapat digunakan untuk menyalurkan pesan dari pengirim kepenerima, sehingga dapat merangsang pikiran, perasaan, perhatian dan minat siswa sedemikian rupa sehingga tejadi proses belajar. Media diartikan sebagai alat komunikasi yang digunakan untuk membawa suatu informasi dari suatu sumber kepada penerima. ${ }^{6}$

Namun demikian, media bukan hanya alat atau bahan aja, akan tetapi hal-hal lain yang memungkinkan siswa dapat memperoleh pengetahuan. Menurut Gerlach dan Ely 1988 secara umum media ini meliputi orang, bahan, peralatan atau kegiatan yang menciptakan kondisi yang memungkinkan siswa memperoleh pengetahuan, keterampilan dan sikap. Jadi dalam pengertian ini, media bukan hanya alat perantara seperti alat yang bersifat audiotori Visual atau lainnya, semacam VCD, komputer, OHP dan sejenisnya, akan tetapi meliputi orang atau manusia sebagai sumber belajar atau juga berupa kegiatan semacam simulasi, peneladanan, karya wisata dan lain sebagainya yang dikondisikan untuk menambah sikap siswa, atau untuk menambah keterampilan.

27.

\footnotetext{
${ }^{2}$ Arief Sadiman, Media Pembelajaran, (Jakarta: PT Raja Grafindo Persada, 2005), h. 6

${ }^{3}$ Ahmad Sabri, Strategi Belajar Mengajar, (Jakarta: PT Ciputat Press, 2005), h. 112.

${ }^{4}$ Ibid.

${ }^{5}$ Basyiruddin Usman, Metodologi Pembelajaran Agama Islam, (Jakarta: Ciputat Press, 2005), h.

${ }^{6}$ Hamzah B. Uno, Porfesi Kependidikan, (Jakarta: Bumi Aksara, 2007), h. 113. 
Pembelajaran adalah proses interaksi peserta didik dengan pendidik dan sumber belajar pada suatu lingkungan belajar yang meliputi guru dan siswa yang saling bertukar informasi. ${ }^{7}$ Menurut Wiki Pedia, pembelajaran adalah merupakan bantuan yang dinberikan pendidik agar dapat terjadi proses perolehan ilmu dan pengetahuan, penguasaan kemahiran dan tabiat serta pembentukan sikap dan kepercayaan pada peserta didik, dengan kata lain, pembelajaran adalah proses untuk membentuk peserta didik agar dapat belajar dengan baik. $^{8}$

Pembelajaran adalah sebuah proses komunikasi antara pembelajar, pengajar dan bahan ajar. Komunikasi tidak akan berjalan tanpa bantuan sarana penyampaian pesan atau media. ${ }^{9}$ Dalam kamus, pembelajaran adalah, proses cara menjadikan orang atau makhluk hidup belajar. ${ }^{10}$ Yusuf Hadi Miarso menyebutkan bahwa pembelajaran adalah suatu usaha yang disengaja, bertujuan dan terkendali agar orang lain belajar atau terjadi perubahan relative menetaf pada diri orang lain. ${ }^{11}$ Pendapat lain, pemebelajaran adalah upaya menciptakan kondisi dengan sengaja agar tujuan pembelajaran dapat dipermudah pencapaiannya. $^{12}$

Media pembelajran secara umum adalah alat bantu proses belajar mengajar, segala sesuatu yang dapat dipergunakan untuk merangsang pikiran, perasaan, perhatian dan kemampuan atau keterampilan belajar, sehingga dapat mendorong terjadinya proses belajar. Batasan ini cukup luas dan mendalam mencakup pengertian, sumber, lingkungan manusia dan metode yang dimanfaatkan untuk tujuan pembelajaran. ${ }^{13}$ Media pembelajaran adalah sebuah alat yang berfungsi untuk menyampaikan proses pembelajaran. $^{14}$

\section{B. Jenis-jenis Media Pembelajaran}

1. Media Audio adalah media yang isi pesannya hanya diterima melalui indera pendengaran. Dilihat dari isi pesan yang diterima, media audio dapat menyampaikan pesan verbal bahasa lisan atau kata-kata merupakan verbal bunyibunyian atau vikalisasi.

2. Media visual adalah media yang hanya mengandalkan indera penglihatan, media visual menampilkan materialnya dengan menggunakan alat proyeksi atau proyektor, karena melalui media ini perangkat lunak soft were yang melengkapi alat proyeksi ini akan dihasilkan suatu bias cahaya atau gambar yang sesuai dengan materi yang diinginkan.

3. Media audio visual disebut juga sebagai media video. Video merupakan media yang digunakan untuk menyampaikan pesan pembelajaran. Dalam media audio

${ }^{7}$ Harianto, Belajar Psikologi.com/pengertian dan tujuan pembelajaran/april 2012.

${ }^{8} \mathrm{Ibid}$.

h. 72 .

${ }^{9}$ Ahmad Lutfi, Pembelajaran Al-Qur'an Hadis, (Direktorat Jenderal Pendidikan Islam, 2009),

${ }^{10}$ TIM Depdikbud, Kamus Besar Bahasa Indonesia, (Jakarta: Balai Pusta, 1995), h. 14

${ }^{11}$ Yusuf Hadi Miarso, Menyemai Benih Teknologi Pendidikan, (Jakarta: Kencana, 2007), h. 545.

${ }^{12}$ Dewi Salam Prawira Dilaga, Mozaik Teknologi Pendidikan, (Jakarta: Kencana, 2004), h. 4.

${ }^{13}$ Harianto, Belajar Psikologi.com/pengertian media pembelajaran,21 januari 2012.

${ }^{14}$ Ahmad Lufti,...., h. 72.

Langkah-langkah. Tatta Herawati 
terdapat dua unsur yang saling bersatu yaitu audio dan visual. Adanya unsur audio memungkinkan siswa untuk dapat menerima pesan pembelajaran melalui pendengaran, sedangkan unsur visual memungkinkan penciptaan pesan belajar melalui bentuk visualisasi. ${ }^{15}$

Dilihat dari jenisnya, dapat dibagi menjadi "media auditif, media visual, dan audio visual" ${ }^{16}$ Untuk lebih jelasnya berikut ini diuraikan secara singkat tentang jenisjenis media pembelajaran tersebut:

a. Media auditif

Media auditif adalah media yang hanya mengandalkan kemampuan suara saja. Media jenis ini berkaitan dengan indera pendengaran. "pesan yang akan disampaikan dituangkan kedalam lambang-lambang audiktif, baik verbal kata-kata atau bahasa lisan maupun nonverbal. Media audio meliputi radio, alat perekam pita magnetic tape recorder, piringan hitam dan laboratorium bahasa. ${ }^{17}$

b. Media visual

Media visual adalah pesan yang disampaikan dituangkan kedalam simbol-simbol komunikasi visual menyangkut indera penglihatan. Media visual ini meliputi: gambar/photo, sketsa, diagram, bagan, grafik, kartun, foster, peta/globe, papan panel dan papan buletin.

c. Media audio visual

Audio visual adalah media yang mempunyai unsur suara dan gambar. Media audio visual mempunyai sifat-sifat sebagai berikut:

1) Kemampuan untuk meningkatkan persepsi

2) Kemampuan untuk meningkatkan kemampuan

3) Kemampuan untuk meningkatkan transfer/pengalihan belajar

4) Kemampuan untuk memberii penguatan reinforcement atau pengetahuan prestasi yang dicapai.

5) Kemampuan untuk meningkatkan retensi. ${ }^{18}$

Sifat-sifat audio visual tersebut selanjutnya diuraikan dalam penjelasan berikut ini:

a) Kemampuan untuk meningkatkan persepsi

b) Media pembelajaran audio visual yang digunakan guru ketika proses belajar mengajar dapat mempengaruhi dan meningkatkan pandangan siswa terhadap kegiatan belajar dan materi yang disampaikan oleh guru.

c) Kemampuan untuk meningkatkan pengertian

d) Media pembelajaran dapat meningkatkan pengertian siswa terhadap materi pelajaran yang disampaikan oleh guru. Dengan menggunakan audio visual bahan pembelajaran akan lebih jelas maknanya sehingga dapat lebih jelas dipahami

\footnotetext{
${ }_{16}^{15}$ Ras- Eko, blog spot.com/2013/04/jenis-jenis media pembelajaran,html.

${ }^{16}$ Saiful Bahria Djamarah dan Aswan Zain, Strategi Belajar Mengajar, (Jakarta: Rineka Cipta, 1997), h. 40-41.

${ }^{17}$ R. Grasindo, 2007), hlm. 13.

${ }^{18}$ Ibid, h. 95

Langkah-langkah Tatta Herawati 
oleh para siswa dan memungkinkan siswa untuk lebih mengerti materi yang sedang dipelajari.

e) Kemampuan untuk meningkatkan transfer/pengalihan belajar

f) Media audio visual mempermudah pekerjaan guru mentransfer ilmu pengetahuan kepada siswa.

g) Kemampuanan untuk memberii pengetahuan reinforcement atau pengetahuan prestasi yang dicapai.

h) Penggunaan media audio visual dalam kegiatan belajar mengajar akan memberikan penguatan kepada siswa untuk meningkatkan prestasi belajar yang diperolehnya. Melalui audio visual siswa dapat merasakan manfaat kegiatan belajar bagi dirinya sendiri sehingga dapat meningkatkan motivasinya untuk belajar lebih giat agar memperoleh prestasi belajar yang maksimal.

i) Kemampuan untuk meningkatkan retensi

j) Penggunaan media audio visual dalam menyampaikan pelajaran akam memberikan kesan kedalam diri siswa sehingga ia dapat lebih lama menyimpan ilmu pengetahuan yang diperolehnya dalam ingatannya.

\section{Kegunaan dan Fungsi Media Pembelajaran}

Sehubungan dengan hal ini Yusuf Hadi Miarso mengemukakan bahwa salah satu kajian teoritik maupun empirik menunjukkan kegunaan media dalam pembelajaran sebagai berikut:

1. Media mampu memberikan rangsangan yang bervariasi kepada otak kita, sehingga otak kita dapat berfungsi secara optimal.

2. Media dapat mengatasi keterbatasan pengamalan yang dimiliki oleh para mahasiswa.

3. Media dapat melampaui batas ruang kelas

4. Media memungkinkan adanya interaksi langsung antara siswa dan lingkunagan.

5. Media menghasilkan keragaman pengalaman. ${ }^{19}$

Kegunaan media pembelajaran ini sangatlah besar manfaatnya dalam proses pembelajaran, dimana jika seorang guru memberikan materi pembelajaran dan siswa disuruh untuk memperhatikan bacaan gurunya dengan baik. Maka dengan sendirinya rangsangan pada salah satu implikasi dalam pemakaian pembelajaran akan terjalin dengan baik dan pembelajarannya menjadi lebih menarik dan tidak membosankan bagi siswa/siswi ketika saat proses belajar mengajar berlangsung.

\section{Kualitas Pembelajaran}

Istilah kualitas mengandung banyak rujukan antara lain adalah:

1. Kesesuain dengan standar tertentu

2. Kesesuaian dengan kebutuhan tertentu

\footnotetext{
${ }^{19}$ Yusuf Hadi Miarso....., h. 458

Langkah-langkah
} 
3. Kesepadanan dengan karakteristik dan kondisi tertentu

4. Keselarasan dengan tuntutan zaman

5. Kesediaan pada saat yang diperlukan

6. Keterandalan dalam berbagai kondisi

7. Daya tarik yang tinggi. ${ }^{20}$

Hamzah B. Uno mengatakan bahwa istilah kualitas tertuju pada suatu benda atau keadaan yang baik. ${ }^{21}$ Sedangkan pendapat Glaser, bahwa kualitas lebih mengarah pada suatu yang baik.

Pembelajaran berasal dari kata "ajar", yang artinya petunjuk yang diberikan kepada orang supaya diketahui. Dari kata "ajar" ini lahir kata kerja "belajar" yang berarti berlatih atau berusaha untuk memperoleh kepandaian atau ilmu dan kata "pembelajaran" berasal dari kata "belajar' yang mendapat awalan "pem" dan akhiran "an" yang merupakan konflik nominal (bertalian dengan prefix verbal meng-) yang mempunyai arti proses. ${ }^{22}$ Pembelajaran adalah upaya membelajarkan siswa. ${ }^{23}$

Pembelajaran secara umum merupakan proses perubahan yakni perubahan dalam perilaku sebagai hasil interaksi seseorang dengan lingkungannya. Secara lengkap pembelajaran merupakan suatu proses yang dilakukan individu untuk sebuah perubahan baru secara keseluruhan sebagai pengalaman diri sendiri dalam interaksi dengan lingkungannya. Ada pengertian lain mengenai pembelajaran diantaranya pembelajaran dan latihan. Keduanya memiliki keterkaitan yang erat meskipun tidak identik. Keduanya menjadi perubahan perilaku aspek perilaku yang berubah karena latihan, adalah perubahan dalam bentuk skill atau keterampilan. Pembelajaran akan lebih berhasil ketika disertai dengan latihan. ${ }^{24}$

Pembelajaran adalah suatu usaha yang disengaja bertujuan, dan terkendali agar orang lain belajar atau terjadi perubahan yang relative menetap pada diri orang lain. Usaha ini dapat dilakukan oleh seorang atau suatu tim yang memiliki kemampuan dan kompetensi dalam merancang dan atau mengembangkan sumber belajar yang diperlukan. ${ }^{25}$

Jadi, membicarakan kualitas pembelajaran berarti mempersoalkan bagaimana kegiatan pembelajaran yang dilakukan selama ini berjalan dengan baik serta menghasilkan keluaran yang baik pula. Agar pelaksanaan pembelajaran berjalan dengan baik dan hasilnya dapat diandalkan. Maka perbaikan pengajaran diarahkan pada pengelolaan proses pembelajaran. ${ }^{26}$

\footnotetext{
${ }^{20}$ Yusuf Hadi Miarso, Menyemai Benih Teknologi Pendidikan, (Jakarta: Kencana, 2007), h. 545

${ }^{21}$ Hamzah B.Uno, Profesi Kependidikan, (Jakarta: Bumi Aksara, 2011), h. 109

22 Departemen Pendidikan dan Kebudayaan, Kamus Besar Bahasa Indonesia, (Jakarta: Balai Pustaka, 1990), h. 664

${ }^{23}$ Hamzah B. Uno......, h. 153

${ }^{24}$ Mohammad Surya, Psikologi Pembelajaran dan Pengajaran, (Bandung: Pustaka Bany Quraisy, 2004), h. 7-11

${ }^{25}$ Yusuf Hadi Muarso, Menyemai......, h. 545

${ }^{26}$ Hamzah B. Uno......, h. 153

Langkah-langkah. 
Berdasarkan deskripsi teoritis tentang kualitas pembelajaran, maka yang akan dikaji menyangkut tiga dimensi strategi, yakni: (1) strategi penyampaian pembelajaran, (2) strategi pengorganisasian pembelajaran, dan (3) strategi pengelolaan pembelajaran. Indikator dari masing-masing strategi yaitu untuk strategi pengorganisasian meliputi strategi makro, dan strategi mikro; sedangkan strategi penyampaian meliputi berbagai metode yang di gunakan dalam strategi pengelolaan menyangkut interaksi antara media, materi, guru dan siswa. Ketiga strategi ini merupakan kegiatan pokok yang merupakan dimensi dari peningkatan kualitas pembelajaran. Adapun indikator dari tiga dimensi tersebut dicantumkan sebagaimana tertera dalam tabel berikut: ${ }^{27}$

\begin{tabular}{|l|l|}
\hline Dimensi Perbaikan Kualitas & Indikator Perbaikan \\
Pembelajaran & Kualitas Pembelajaran \\
\hline Strategi pengorganisasian & Menata bahan ajar yang akan diberikan \\
pembelajaran & selama satu caturwulan atau satu semester. \\
& Menata bahan ajar yang akan diberikan setiap \\
& kali pertemuan \\
& Memberikan pokok-pokok materi kepada \\
& siswa yang akan diajarkan \\
& Membuat rangkuman atas materi yang \\
diajarkan setiap kali pertemuan \\
Menetapkan materi-materi yang akan di bahas \\
& secara bersama \\
& Memberikan tugas kepada siswa terhadap \\
& materi tertentu yang akan dibahas secara \\
& mandiri. \\
& Membuatkan format penilaian atas \\
& penguasaan setiap materi. \\
\hline Strategi penyampaian & Menggunakan berbagai metode dalam \\
pembelajaran & penyampaian pembelajaran \\
& Menggunakan berbagai media dalam \\
pembelajaran \\
Menggunakan berbagai teknik dalam \\
pembelajaran.
\end{tabular}

${ }^{27}$ Ibid.

Langkah-langkah Tatta Herawati 
Jadi setiap guru sebagai manajer dalam proses pembelajaran harus memperhatikan upaya peningkatan kualitas belajar secara berkelanjutan. Bagaimanapun, tanpa adanya upaya kreatif dan inovatif dari guru terhadap pembelajaran disetiap sekolah secara terencana dan terarah maka tidak akan mungkin dicapai kualitas pembelajaran. Karena itu, peningkatan kualitas pembelajaran merupakan konsekuensi dan evaluasi, supervise, dan pengawasan yang dilaksanakan disekolah.

\section{E. Langkah-langkah Pengembangan Media Pembelajaran Menuju Kualitas}

Secara garis besar kegiatan pengembangan media pembelajaran terdiri atas tiga langkah besar yang harus dilalui, yaitu, kegiatan perencanaan produksi dan penilaian. Sementara itu, dalam rangka melakukan desain, atau rancangan pengembangan program media. Menurut Arif Sadiman, dkk, yang dikutip oleh sudarwan memberikan urutan langkah-langkah yang harus diambil dalam pengembangan program media menjadi 6 langkah sebagai berikut: ${ }^{28}$

\section{Menganalisis kebutuhan dan karakteristik siswa}

Kebutuhan dalam proses belajar mengajar adalah kesenjangan antara apa yang dimiliki siswa dengan apa yang diharapkan. Contoh jika kita mengharapkan siswa mampu membandingkan proses perpindahan kalor dengan cara konduksi, konveksi dan radiasi.

Setelah kita menganalisis kebutuhan siswa, maka kita juga perlu menganalisis karakteristik siswanya, baik menyangkut kemampuan pengetahuan atau keterampilan yang telah dimiliki siswa sebelumnya. Cara mengetahuinya bisa dengan tes atau dengan yang lainnya. Langkah ini dapat disederhanakan dengan cara menganalisa topik-topik materi ajar yang dipandang sulit dan karenanya memerlukan bantuan media. Pada langkah ini sekaligus pula dapat ditentukan ranah tujuan pembelajaran yang hendak dicapai, termasuk rangsangan indera mana yang diperlukan audio, visual, gerak, atau diam.

Contoh melakukan identifikasi kebutuhan dan karakteristik siswa: siswa SMA diharapkan sudah memiliki kemampuan membandingkan proses perpindahan kalor dengan cara konduksi, konveksi dan radiasi dan mengaplikasikannya dalam kehidupan sehari-hari.

\section{Merumuskan tujuan pembelajaran intruksional objektive dengan operasional dan khas.}

Untuk dapat merumuskan tujuan intruksional dengan baik, ada beberapa ketentuan yang harus diingat, yaitu: tujuan pembelajaran harus berorientasi kepada siswa; artinya tujuan itu benar-benar harus menyatakan adanya perilaku siswa yang dapat dilakukan atau diperoleh setelah proses belajar dilakukan.

${ }^{28}$ Sudarwan Danim, Media Komunikasi Pendidikan, (Jakarta: Bumi Aksara, 1994), h. 40. Langkah-langkah... . Tatta Herawati 
Sebagai tujuan pembelajaran hendaknya memiliki empat unsur pokok yang dapat kita akronomkan dalam ABCD Audience, Behavior, Condition, dan degree. Penjelasan dari masing-masing komponen tersebut sebagai berikut:

a. Audience adalah menyebutkan sasaran/audien yang dijadikan sasaran pembelajaran

b. Behavior adalah menyatakan perilaku spesifik yang diharapkan atau yang dapat dilakukan setelah pembelajaran berlangsung

c. Condition adalah menyebutkan kondisi yang bagaimana atau dimana sasaran dapat mendemonstrasikan kemampuannya atau keterampilannya

d. Degree adalah menyebutkan batasan tingkatan minimal yang diharapkan dapat dicapai.

\section{Merumuskan butir-butir materi secara terperinci yang mendukung tercapainya tujuan.}

Penyusunan rumusan butir-butir materi adalah dilihat dari sub kemampuan atau keterampilan yang dijelaskan dalam tujuan khusus pembelajaran, sehingga materi yang disusun adalah dalam rangka mencapai tujuan diharapkan dari kegiatan proses belajar mengajar tersebut. Setelah daftar butir-butir materi dirinci maka langkah selanjutnya adalah mengurutkannya dari yang sederhana sampai kepada tingkatan yang lebih rumit, dan dari hal-hal yang konkrit kepada yang abstrak.

a. Mengembangkan Instrument Pengukuran

Alat pengukur keberhasilan seyogyanya dikembangkan terlebih dahulu sebelum naskah tertulis. Dan instrument pengukur ini harus dikembangkan sesuai dengan tujuan yang akan dicapai dan dari materi-materi pembelajaran yang disajikan. Bentuk instrument pengukurannya bisa dengan tes, pengamatan, penugasan atau checklist prilaku.

Instrument tersebut akan digunakan oleh pengembang media, ketika melakukan tes uji coba dari program media yang dikembangkannya. Misalkan instrument pengukurnya tes, maka siswa nanti akan diminta mengerjakan materi tes tersebut. Kemudian dilihat bagaimana hasilnya. Apakah siswa menunjukkan penguasaan materi yang baik atau tidak dari efek media yang digunakannya atau dari materi yang dipelajarinya melalui sajian media. Jika tidak dimanakah letak kekurangannya. Dengan demikian, maka siswa diminta tanggapan tentang media tersebut, baik dari segi kemenarikan maupun efektifitas penyajiannya.

Sebagai salah satu contoh tentang instrument pengukur keberhasilan dari media yang dikembangkan oleh guru adalah sebagai berikut: 


\begin{tabular}{|l|l|l|}
\hline Rumusan Tujuan & Rumusan Materi & $\begin{array}{l}\text { Instrumen Pengukur } \\
\text { Tes }\end{array}$ \\
\hline $\begin{array}{l}\text { Siswa dapat } \\
\text { menyebutkan macam- } \\
\text { macam besaran pokok } \\
\text { dan besaran turunan }\end{array}$ & $\begin{array}{l}\text { Nama-nama besaran } \\
\text { pokok dan turunan }\end{array}$ & $\begin{array}{l}\text { Sebutkan minimal 5 } \\
\text { macam-macam } \\
\text { besaran pokok dan } \\
\text { besaran turunan }\end{array}$ \\
\hline
\end{tabular}

Dari contoh di atas, jelaslah bahwa penyusunan instrument ukur harus berdasar dari rumusan tujuan dan materi pembelajaran yang akan di ajarkan melalui media pembelajaran tersebut.

\section{b. Menulis Naskah Media}

Naskah media adalah bentuk penyajian materi pembelajaran melalui media rancangan yang merupakan penjabaran dari pokok-pokok materi yang telah disusun secara baik seperti yang telah dijelaskan di atas. Supaya materi pembelajaran itu dapat disampaikan melalui media, maka materi tersebut perlu dituangkan dalam tulisan atau gambar yang kita sebut naskah program media.

Naskah program media maksudnya adalah sebagai penuntun kita dalam memproduksi media. Artinya menjadi penuntut kita dalam mengambil gambar dan merekam suara. Karena gambar ini bersisi urutan gambar dan grafis yang perlu diambil oleh kamera atau bunyi dan suara yang harus direkam.

Namun demikian, sebelum naskah ditulis, maka terlebih dahulu disusun garisgaris besar program media GBPM dan rancangan isi medianya.

c. Mengadakan Tes atau Uji Coba dan Revisi

Tes adalah kegiatan untuk menguji atau mengetahui tingkat efektifitas dan kesesuaian media yang dirancang dengan tujuan yang diharapkan dari program tersebut. Suatu program media yang oleh pembuatannya dianggap telah baik, tapi bila program itu tidak menarik, atau sukar dipahami atau tidak merangsang proses belajar bagi siswa yang ditujunya, maka program semacam ini terntu saja tidak dikatakan baik.

Tes atau uji coba tersebut dapat dilakukan baik melalui perseorangan atau melalui kelompok kecil atau juga melalui tes lapangan, yaitu dalam proses pembelajaran yang sesungguhnya dengan menggunakan media yang dikembangkan. Sedangkan revisi adalah kegiatan untuk memperbaiki hal-hal yang dianggap perlu mendapatkan perbaikan atas hasil dari tes.

Jika semua langkah-langkah tersebut telah dilakukan dan telah dianggap tidak ada lagi yang perlu direvisi, maka langkah selanjutnya adalah media tersebut siap untuk diproduksi. Akan tetapi bisa saja terjadi setelah dilakukan produksi ternyata setelah disebarkan atau disajikan ada beberapa kekurangan dari aspek materi atau kualitas sajian medianya gambar atau suara maka dalam kasus seperti ini dapat pula dilakukan perbaikan revisi terhadap aspek yang dianggap kurang. Hal ini dilakukan untuk mendapatkan kesempurnaan dari media yang dibuat, sehingga para penggunanya akan mudah menerima pesan-pesan yang disampaikan melalui media tersebut. 
Sedangkan menurut Gerlach dan Ely, bahwa pengembangan media pembelajaran tersebut harus relevan dengan tujuan, relevan dengan bahan pelajaran, relevan dengan metode, relevan dengan kondisi siswa, relevan dengan evaluasi, dengan kemampuan guru dan pengembangannya dapat membangkitkan minat dan kemampuan siswa.

\section{PENUTUP}

Media pembelajaran adalah alat bantu dalam kegiatan belajar mengajar yang berfungsi untuk memudahkan penyampaian pelajaran. Penggunaan media pembelajaran dapat memberikan pengaruh yang besar terhadap peningkatan kualitas pembelajaran, maka untuk dapat meningkatkan kualitas pembelajaran. Penggunaan media pembelajaran diharapkan mengikuti prinsip-prinsip dan langkah-langkah pengembangannya. Diantara langkah-langkah pengembangannya media pembelajaran tersebut yaitu menganalisis kebutuhan dan karakteristik siswa, merumuskan tujuan pembelajaran, merumuskan butir-butir materi secara terperinci yang mendukung tercapainya tujuan, mengembangkan instrument pengukuran, menulis naskah media, dan mengadakan tes atau uji coba dan Revisi.

\section{DAFTAR PUSTAKA}

Ahmad Lutfi, Pembelajaran Al-Qur'an Hadis, Direktorat Jenderal Pendidikan Islam, 2009.

Ahmad Sabri, Strategi Belajar Mengajar, Jakarta: PT Ciputat Press, 2005.

Arief Sadiman, Media Pembelajaran, Jakarta: PT Raja Grafindo Persada, 2005.

Basyiruddin Usman, Metodologi Pembelajaran Agama Islam, Jakarta: Ciputat $\quad$ Press, 2005.

Departemen Pendidikan dan Kebudayaan, Kamus Besar Bahasa Indonesia, Jakarta: Balai Pustaka, 1990.

Dewi Salam Prawira Dilaga, Mozaik Teknologi Pendidikan, Jakarta: Kencana, 2004.

Hamzah B.Uno, Profesi Kependidikan, Jakarta: Bumi Aksara, 2011.

Harianto, Belajar Psikologi.com/pengertian dan tujuan pembelajaran/april 2012.

Mohammad Surya, Psikologi Pembelajaran dan Pengajaran, Bandung: Pustaka Bany Quraisy, 2004.

Ras- Eko, blog spot.com/2013/04/jenis-jenis media pembelajaran,html.

Saiful Bahria Djamarah dan Aswan Zain, Strategi Belajar Mengajar, Jakarta: Rineka Cipta, 1997.

Sudarwan Danim, Media Komunikasi Pendidikan, Jakarta: Bumi Aksara, 1994.

Langkah-langkah Tatta Herawati 
TIM Depdikbud, Kamus Besar Bahasa Indonesia, Jakarta: Balai Pusta, 1995.

Yusuf Hadi Miarso, Menyemai Benih Teknologi Pendidikan, Jakarta: Kencana, 2007.

Yusuf Hadi Miarso, Menyemai Benih Teknologi Pendidikan, Jakarta: Kencana, 2007. 